\title{
Mapping the potential of the State of Minas Gerais, Brazil, in generating electricity from biogas from anaerobic digestion of vinasse
}

\section{Tamires Dantas dos Santos*, Eduardo de Aguiar do Couto and Eliane Maria Vieira}

Universidade Federal de Itajubá. Campus Itabira. Instituto de Ciências Puras e Aplicadas. Rua Irmã Ivone Drumond, 200. Distrito Industrial II. Itabira-MG, Brazil (CEP ).*E-mail: tamiresdantas@unifei.edu.br.

\begin{abstract}
This study aimed to map and estimate the potential of electricity generation from biogas produced through the anaerobic digestion process of vinasse in the state of Minas Gerais, Brazil, focusing on the energy use of an electric powered otto cyclemotor generator set. The potential for electric power generation was estimated from the amount of sugarcane produced in the 2018/2019 harvest in each municipality of the State. Then, the map was made with the spatialization of the information, in order to denote the municipal potentialities of the regions with the highest available energy indices. Energy availability was in the order of $746.43 \mathrm{GWh}$ for each sugarcane crop, being more concentrated in the Triangulo Mineiro Region. Therefore, the use of this biomass waste into the anaerobic digestion process to produce electricity from biogas represents an environmental solution, an economical alternative and a social benefit.
\end{abstract}

Keywords: Anaerobic digestion; Biorefineries; Bioenergy; Ethanol; Sugarcane.

Resumo. Mapeamento do potencial do Estado de Minas Gerais na geração de eletricidade a partir de biogás da digestão anaeróbica da vinhaça. Este trabalho objetivou estimar o potencial de geração de biogás no processo de digestão anaeróbia da vinhaça no âmbito do estado de Minas Gerais, Brasil, com foco no aproveitamento energético para geração de energia elétrica considerando um conjunto moto-gerador de ciclo otto. Estimouse o potencial de geração de energia elétrica a partir da quantidade de cana-de-açúcar produzida na safra 2018/2019 em cada município do estado. Procedeu-se, então, a confecção do mapa com a espacialização da informação, a fim de se denotar as potencialidades municipais e as regiões com maiores índices de energia disponível. A disponibilidade energética foi da ordem de 746,43 GWh a cada safra de cana-de-açúcar, estando mais concentrada na região do Triângulo Mineiro. A submissão deste resíduo ao processo de digestão anaeróbia com aproveitamento
Received

October 06, 2020

Accept

June 10, 2021

Available online

June 27, 2021

Released

August 31, 2021

Open Access

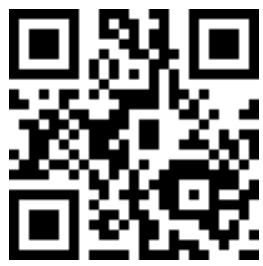

\section{ORCID}

(D) $0000-0002-9190-4018$

Tamires Dantas dos Santos

(D) 0000-0002-2976-9302

Eduardo de Aguiar do Couto

(D) 0000-0003-1749-6105 Eliane Maria Vieira 
energético do biogás produzido representa uma solução ambiental, uma alternativa econômica e um benefício social.

Palavras-chaves: Bioenergia; Biorefinaria; Cana-de-açúcar; Digestão anaeróbia; Etanol.

\section{Introduction}

Energy is essential for the development of contemporary activities and, because of the high population growth worldwide, there is a constant increase in the global energy demand. In the pursuit of sustainability, governments and industries are under pressure to explore clean and renewable energy sources. Biomass derived from animal, plant, and waste products are relevant feedstock alternatives for the expansion of the energetic matrix. Anaerobic digestion stands out as one of the most efficient technologies to convert biomass waste into clean and renewable energy, such as methane biogas. Additionally, the production of biogas can significantly contribute to the reduction of greenhouse gas emissions by replacing fossil fuels for energy generation (Moraes et al., 2017).

Vinasse is the main by-product of the production of ethanol from sugarcane. It consists mainly of water, organic matter content, and minerals (Wilkie et al., 2000). Because of the high organic content, vinasse is a strong environmental pollutant with biochemical oxygen demand (BOD) and chemical oxygen demand (COD) values up to 17.000 and $33.000 \mathrm{mg} / \mathrm{L}$ respectively (Moraes et al., 2015). Besides, due to the high concentration of nutrients, vinasse is often used in fertigation, which is a crucial process of nutrient recycling within the sugarcane industry and the main form of disposal of this residue (Leme e Seabra, 2017). However, the use of untreated vinasse as fertilizer can lead to the contamination of soil and water resources (Nakashima e Oliveira Junior, 2020).

Therefore, it is important to discuss alternatives forms of treatment, disposal, and reuse of this abundant residue from ethanol production. Anaerobic digestion is one of the most promising strategies for the treatment of vinasse. This biological treatment process can improve the quality of the effluent by reducing its organic load. Concomitantly, the anaerobic digestion of vinasse produces methane and hydrogen-rich biogas that can be used for electric or thermal energy generation. The most used technology in this process is the up-flow anaerobic sludge blanket (UASB) reactor (Salomon, 2007). The treated vinasse effluent, which has lower organic matter and similar essential inorganic nutrients to the influent, can then be used as an environmentally safe biofertilizer for crops (Moraes et al., 2015). Thus, the use of vinasse for the production of biogas can be an interesting alternative from both environmental and economic perspectives, exploring the concept of biorefineries in the sustainable production of ethanol and sugar. Public policies can help speed up the implementation of biodigesters in ethanol refineries and the use of treated vinasse on fertigation (Fuess e Zaiat, 2018).

The state of Minas Gerais has several ethanol refineries with the potential to implement anaerobic digester for the treatment of vinasse and the production of biogas. Other studies have determined the potential of biogas production from vinasse; however, to our knowledge, this is the first study to map sugar cane production and estimate electric energy generation potential for all municipalities of the State. Therefore, the present study aimed to map and estimate the potential of electricity production from biogas produced through the anaerobic digestion of vinasse. The information obtained from this study can be used to subsidize the destination of investments and the adoption of anaerobic digestion as a technology for the biological treatment of vinasse from sugarcane refineries. 


\section{Materials and methods}

\section{Estimation of vinasse production}

The potential production of vinasse of the State of Minas Gerais (Figure 1) was estimated using data from the Brazilian Institute of Geography and Statistics (IBGE). The amount of sugarcane produced (in tons) in municipality city in Minas Gerais in 2018 reported by the Municipal Agricultural Production Reports (IBGE, 2018). In the State of Minas Gerais, 37\% of the sugarcane harvested in 2018/2019 was destined for the production of sugar (SIAMIG, 2019). Therefore, this study considered that the remaining $63 \%$ production was used for the production of ethanol. This study also considered that approximately 51.2 L of ethanol are produced per ton of sugarcane (IBGE, 2018), and each liter of ethanol generates approximately $13 \mathrm{~L}$ of vinasse (Salomon, 2007).

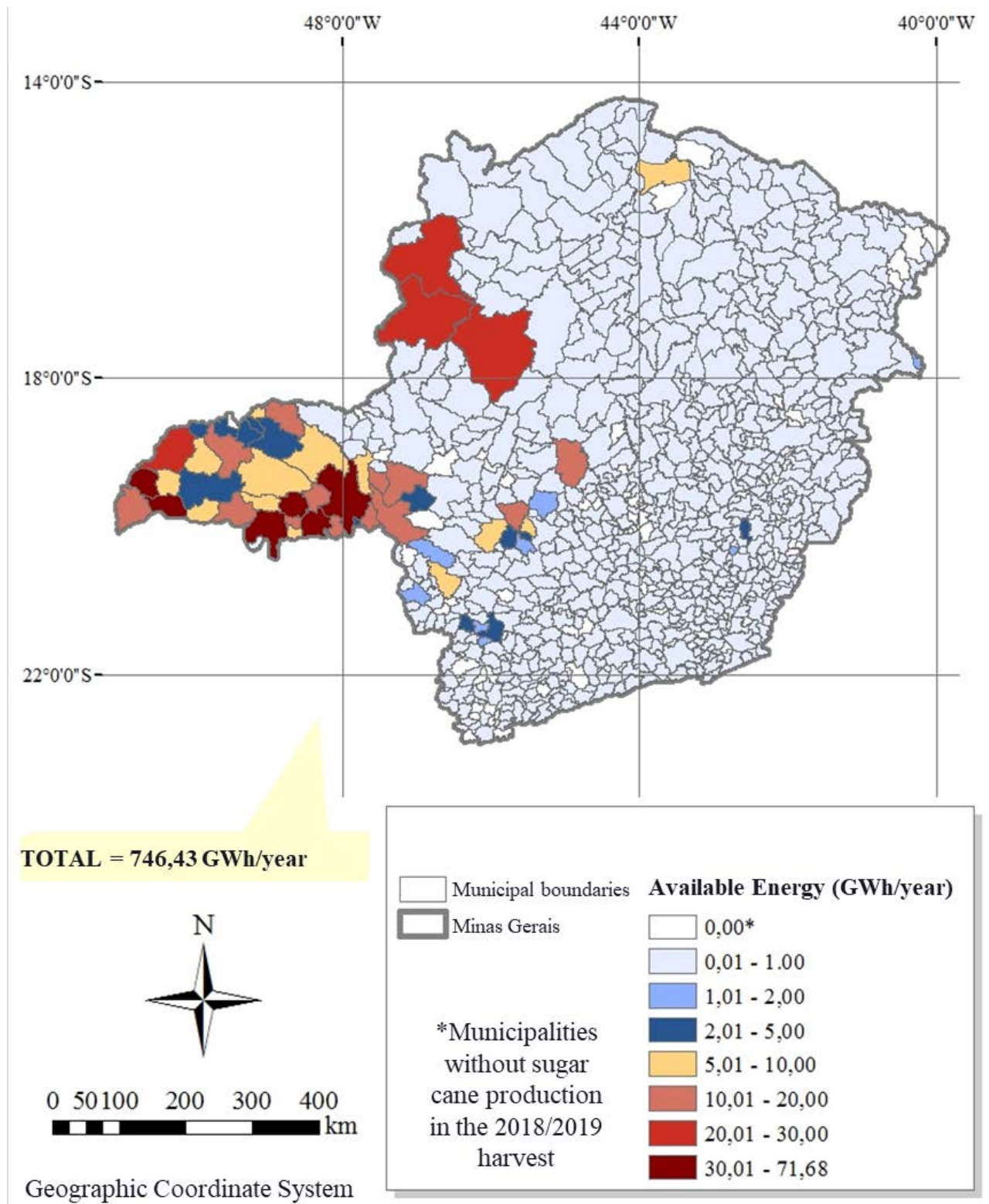

SIRGAS 2000

Figure 1. Map of electricity generation potential from biogas of vinasse for each municipality of the State of Minas Gerais. 


\section{Estimation of biogas production}

The production of biogas and methane was estimated as the total reduction of organic matter in the treated vinasse effluent, from the COD load influent to the reactor. Thus, the production of methane from each municipality of Minas Gerais was estimated, as a function of vinasse production, following equation 1 (Chernicharo, 1997).

$$
\mathrm{COD}_{C H 4}=\boldsymbol{Q} *\left(\boldsymbol{S}_{\mathbf{0}}-\boldsymbol{S}\right)-\boldsymbol{Y}_{\text {obs }} * \boldsymbol{Q} * \boldsymbol{S}_{\mathbf{0}}
$$

Where: $\mathrm{COD}_{\mathrm{CH} 4}$ represents the COD charge converted to methane $\left(\mathrm{kg} \mathrm{COD}_{\mathrm{CH} 4} / \mathrm{year}\right), \mathrm{Q}$ is the flow of vinasse produced $\left(\mathrm{m}^{3} /\right.$ year), $\mathrm{S}_{0}$ is the influent COD concentration $\left(\mathrm{kg} \mathrm{COD} / \mathrm{m}^{3}\right), \mathrm{S}$ is the effluent COD concentration $\left(\mathrm{kg} \mathrm{COD} / \mathrm{m}^{3}\right)$, and $\mathrm{Y}_{\mathrm{obs}}$ is the coefficient of the production of solids in the system in terms of COD ( $\mathrm{kg} \mathrm{COD}$ sludge $/ \mathrm{kg} \mathrm{COD}_{\text {applied }}$ ).

The concentration of influent COD $\left(\mathrm{S}_{0}\right)$ was determined according to the removal efficiency of the UASB reactor. The influent COD of the vinasse from mixed wort was equivalent to $45 \mathrm{~kg} / \mathrm{m}^{3}$ (Ludovice, 1997). Also, the COD removal efficiency of the UASB reactor is between $65 \%$ and $75 \%$ for domestic sewage (Chernicharo, 1997). Hence, this study considered a removal efficiency of $70 \%$. Therefore, the effluent COD concentration was defined according to equation 2 .

$$
\boldsymbol{S}=(\mathbf{1}-\boldsymbol{E}) * \boldsymbol{S}_{\mathbf{0}}
$$

Where: S represents the effluent COD concentration $\left(\mathrm{kg} \mathrm{COD} / \mathrm{m}^{3}\right), \mathrm{E}$ is the efficiency, and $\mathrm{S}_{0}$ is the influent COD concentration $\left(\mathrm{kg} \mathrm{COD} / \mathrm{m}^{3}\right)$.

Besides, Chernicharo (1997) states that the coefficient of production of solids in the system, in terms of COD $\left(\mathrm{Y}_{\mathrm{obs}}\right)$ varies between 0.11 to $0.23 \mathrm{~kg} \mathrm{COD}$ sludge $/ \mathrm{kg} \mathrm{COD}$ applied. Therefore, the present study considered the median value of production of solids in the system, equivalent to $0.17 \mathrm{~kg} \mathrm{COD}$ sludge $/ \mathrm{kg} \mathrm{COD}_{\text {applied. }}$

Equation 3 was applied to correct the methane flow produced according to the daily flow (Chernicharo, 1997).

$$
\mathrm{Q}_{\mathrm{CH}_{4}}=\mathrm{COD}_{\mathrm{CH}_{4}} /\left(\frac{\mathrm{P} * \mathrm{~K}}{\mathrm{R} *(273+\mathrm{T})}\right)
$$

Where: $Q_{\mathrm{CH} 4}$ represents the methane flow produced ( $\mathrm{m}^{3} /$ year), $\mathrm{COD}_{\mathrm{CH}}$ : COD charge converted to methane ( $\mathrm{kg} \mathrm{COD} \mathrm{CH}_{4} /$ year), $\mathrm{P}$ is the atmospheric pressure (atm), $\mathrm{K}$ is $\mathrm{CH}_{4}$ equivalent COD ( $\left.\mathrm{g} \mathrm{COD} / \mathrm{mol} \mathrm{CH}_{4}\right), \mathrm{R}$ is a gas constant (atm.L/mol. K), and $\mathrm{T}$ is reactor temperature $\left({ }^{\circ} \mathrm{C}\right.$ ). At the atmospheric pressure (P) equivalent to $1 \mathrm{~atm}$, the COD corresponding to $1 \mathrm{~mol}^{\circ} \mathrm{CH}_{4}(\mathrm{~K})$ was defined as $64 \mathrm{~g} \mathrm{COD} / \mathrm{mol} \mathrm{CH}_{4}$ and the gas constant (R) as $0.08206 \mathrm{~atm} . \mathrm{L} / \mathrm{mol}$. K.

The efficiency of removing COD from vinasse is higher, and the adaptation time of the inoculum is shorter, when the reactor operates in the mesophilic phase compared with 
the thermophilic phase (Ribas, 2007). Furthermore, the mesophilic phase also presents greater stability of COD removal efficiency compared with the thermophilic phase (Khemkhao et al., 2012). Therefore, the temperature was considered to be $35{ }^{\circ} \mathrm{C}$. Therefore, the considered temperature was $35^{\circ} \mathrm{C}$. Thus, the flow of methane produced in the anaerobic degradation of vinasse was estimated for each city of Minas Gerais per crop year. With that, it was possible to calculate the electricity potential of methane gas.

\section{Estimation of electricity generation}

Regarding the conversion mechanism, the internal combustion (IC) engines are the most common machines most used in the generation of electric energy from biogas as the primary fuel. These engines are more efficient and cost-effective (Pecora et al., 2009). The internal combustion of the Otto cycle IC engine has a performance in the range of $22 \%$ to $28 \%$ (Suzuki et al., 2011). For the present estimate, an Otto cycle engine with nominal power $200 \mathrm{~kW}$ and efficiency equivalent to $27 \%$ was considered. The energy potential was determined according to equation 4 .

$$
\mathrm{PE}=\left(\mathbf{Q}_{\mathrm{CH} 4} * \mathrm{PCI}_{\mathrm{CH} 4} * \eta * 4,1868\right) / 31.536 .000
$$

Where: PE represents the electrical power $(\mathrm{kW}), \mathrm{Q}_{\mathrm{CH} 4}$ is methane flow $\left(\mathrm{m}^{3} /\right.$ year), $\mathrm{PCI}_{\mathrm{CH} 4}$ is the lower calorific power of methane $\left(\mathrm{kcal} / \mathrm{m}^{3}\right), \boldsymbol{\eta}$ represents the efficiency of conversion technology, the value 4.1868 is the conversion factor used to convert "kcal" to "kJ", and 31.536 .000 is the year to second conversion factor.

Based on the value found for the electrical power of the biogas, the potential electrical energy generation was then calculated considering that the engine operated 24 h, every day of the year, according to equation 5 .

$$
E_{e l e}=\boldsymbol{P E} * \boldsymbol{T}_{\text {op }}
$$

Where, $E_{\text {ele }}$ represents the available electrical energy $(\mathrm{kWh}), \mathrm{PE}$ is the electrical power $(\mathrm{kW})$, and the $\mathrm{T}_{\mathrm{op}}$ is operating time.

Table 1 summarizes the parameters used to estimate the generation of electric power by anaerobic degradation of vinasse, based on the amount of sugarcane produced in each municipality in the State of Minas Gerais.

Table 1. Parameters used for the estimation of electric energy generation potential of biogas from the anaerobic digestion of vinasse.

\begin{tabular}{lcc}
\hline Parameter & Indicator & Reference \\
\hline Ethanol & $51.2 \mathrm{~L} /$ ton sugarcane & SIAMIG (2019) \\
Vinasse & $13 \mathrm{~m}^{3} / \mathrm{m}^{3}$ ethanol & Salomon (2007) \\
CQO inflow (S0) & $45 \mathrm{~kg} / \mathrm{m}^{3}$ vinasse & Ludovice (1997) \\
Reactor efficiency & $70 \%$ & Chernicharo (1997) \\
Yobs $_{\text {Temperature }}$ & $0.17 \mathrm{kgCOD}$ sludge $/ \mathrm{kgCOD}$ applied & Chernicharo (1997) \\
PCICH4 & $35^{\circ} \mathrm{C}$ & Ribas (2007) \\
$\eta$ & $8.500 \mathrm{kcal} / \mathrm{m}^{3}$ & Lora e Venturini $(2012)$ \\
\hline
\end{tabular}




\section{Spatialization of data}

The estimation of electricity generation, from biogas produced by the anaerobic digestion of vinasse, of each municipality in the State of Minas Gerais was plotted against the GIS data to spatialize the information of energetic potential across the State. In the ArcGis 10.9 software, the calculations of energy generation were imported and inserted in the shapefile attributes table of the municipalities of Minas Gerais through the FID field concomitant to the two files. This step made it possible to spatially analyze the energy available in each city and carry out an isolated assessment of the potential of each municipality. It also allowed the identification of the cities with the greatest total available energy and the regions with the highest electricity production potential.

\section{Results and discussion}

The concentration of effluent COD was equivalent to $13.5 \mathrm{~kg} / \mathrm{m}^{3}$, making it possible to determine the COD load converted to methane. The methane flow was obtained from the total vinasse volume available for the anaerobic digestion process in each city of Minas Gerais in the 2018/2019 harvest. Figure 1 shows the spatialization of the estimated potential for electricity generation from methane production in each municipality, based on the anaerobic digestion of vinasse. Uberaba had the highest potential for available energy due to its high production of sugarcane (Figure 2). In this city, a total of 6.8 million tons of sugarcane was harvested in 2018/2019. Therefore, the total estimated production of ethanol was $219.340 \mathrm{~m}^{3}$, and, consequently, the estimated production of vinasse was 2.8 million $\mathrm{m}^{3}$. This volume of vinasse can generate an energy output of $746.43 \mathrm{GWh} /$ year.

The municipalities from the Triângulo Mineiro and the Northwest region of Minas Gerais had the greatest potential to generate electricity through anaerobic digestion of vinasse (Figure 1). However, only three cities - João Pinheiro, Unaí, and Paracatu - amongst the top ten municipalities with the highest potential energy available from vinasse, were located outside the Triangle Mineiro region (Figure 2). The climate and soil characteristics of this region are favorable to the cultivation of sugarcane, which explains the intense development of the sugar and ethanol industry in the local economy. Additionally, the region received incentives from the Federal Government aiming to increase ethanol production, which resulted in the expansion of the sugarcane plantation area (Castanho e Souto, 2013).

Hydrated ethanol is one of the leading products of agricultural-based agribusiness in this State, in terms of participation in the gross value of production and, thus, the local economy (Barros et al., 2019). However, this study demonstrated that there is also a high production of vinasse. Therefore, it is essential to increase the treatment and application of liquid effluents from the production process to reduce the environmental and socioeconomic impacts of the ethanol industry. Anaerobic digestion is a sustainable strategy for the treatment of vinasse with the potential to reduce greenhouse gas emissions through the capture of the biogas, which can be used as a renewable source of energy. The anaerobic digestion of the vinasse could potentially provide $746.43 \mathrm{GWh} /$ year per harvest of sugarcane to the State of Minas Gerais. The generation of this alternative energy can be particularly attractive in regions where the power supply is limited, considering the advantages of this decentralized source of electricity production. Thus, the anaerobic digestion of vinasse can bring both ecological and economic benefits to the industry. However, the economic and environmental assessments are scarce, as this concept is still a novelty within the Brazilian bioethanol sector. 


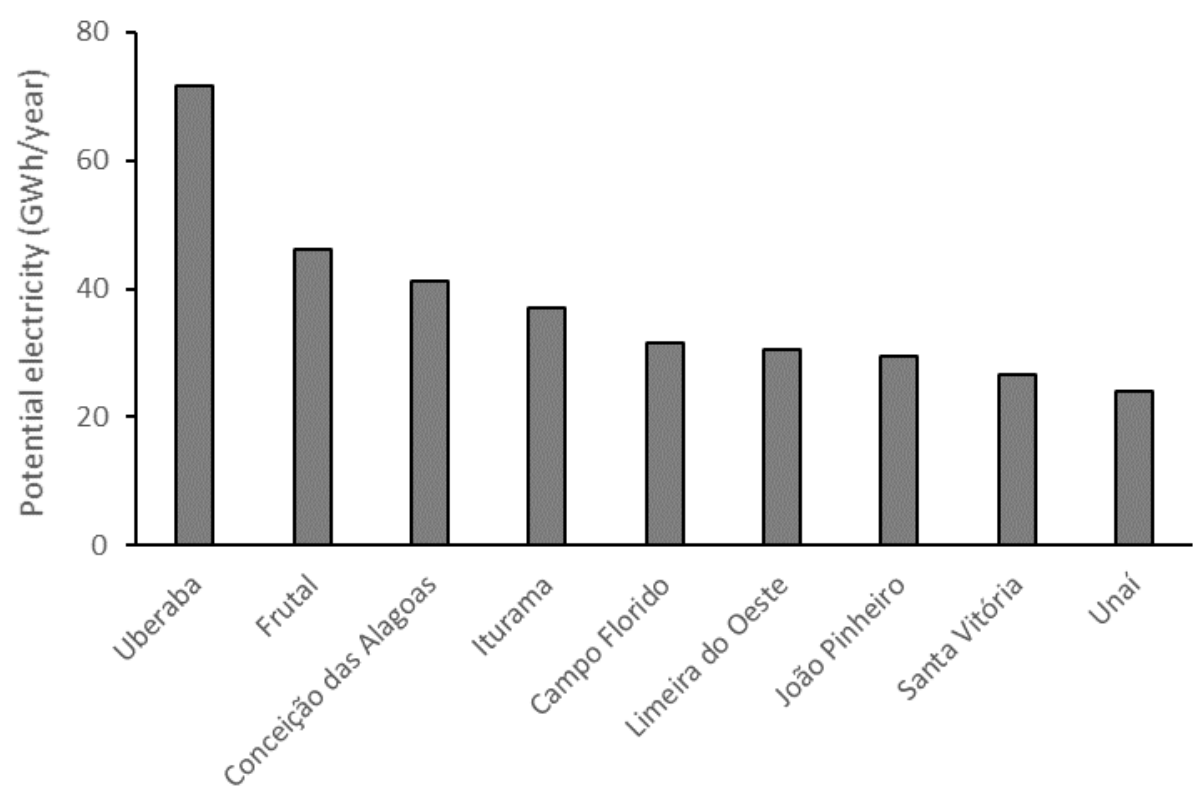

Figure 2. Top 10 municipalities with the greatest potential for electric energy generation from vinasse.

The present study demonstrated that the use of biogas as a renewable source of energy could increase profitability in biorefineries, reducing production costs and environmental impacts. Nevertheless, political, economic, scientific, and environmental incentives are necessary for a practical and widespread application of such process in the ethanol production chain. For instance, the government can secure financial support for biodigester projects and increase restriction standards for vinasse disposal (Fuess e Zaiat, 2018). By mapping the energy potential of biogas from anaerobic digestion of vinasse in the territory of Minas Gerais, regional potentials for energy generation are highlighted. The state of Minas Gerais has an available energy potential of $746.43 \mathrm{GWh} /$ year from biogas produced with the anaerobic digestion of vinasse. Therefore, incentive policies can be developed to expand the use of biogas, promoting economic and social benefits to producers and the community. In addition to providing environmental gains by enabling the reduction of greenhouse gas emissions, it avoids the incorrect disposal of this residue with high polluting potential.

\section{Conclusions}

The State of Minas Gerais, Brazil, has a high potential to generate electricity from the anaerobic digestion of vinasse, particularly within the Triângulo Mineiro region, which is strongly influenced by the sugar and alcohol industry. The anaerobic digestion of vinasse is a promising option to explore the energy potential of this residue and add value to ethanol production. With the current production of sugarcane and, consequently, vinasse, the State could generate $746.43 \mathrm{GWh} /$ year, which can be attractive in regions with limited energy supply. Furthermore, the production and use of biogas and methane as a renewable energy source offers multiple environmental solutions, as it reduces greenhouse gas emissions and the pollution risks to the environment and public health. 


\section{Conflicts of interest}

The authors declare that they no have conflicts of interest.

\section{References}

Barros, G. S. C.; Castro, N. R.; Machado, G. C.; Almeida, F. M. S.; Silva, A. F.; Fachinello, A. L. Boletim PIB do agronegócio do Estado de Minas Gerais. Piracicaba: Centro de Estudos Avançados em Economia Aplicada, 2019. Available from: <https://www.cepea.esalq. usp.br/upload/kceditor/files/PIBAGRO Minas Gerais_junho_19.pdf>. Accessed on: Nov. 20, 2019.

Castanho, R. B.; Souto, T. S. Produção de cana de açúcar na Mesorregião do Triângulo Mineiro e Alto Paranaíba, Minas Gerais, Brasil. Brazilian Geographical Journal, v. 4, no. 1, p. 27-54, 2013.

Chernicharo, C. L. Reatores anaeróbios. Belo Horizonte: Departamento de Engenharia Sanitária e Ambiental, UFMG, 1997.

Fuess, L. T.; Zaiat, M. Economics of anaerobic digestion for processing sugarcane vinasse: Applying sensitivity analysis to increase process profitability in diversified biogas applications. Process Safety and Environmental Protection, v. 115, p. 27-37, 2018. https://doi.org/10.1016/j.psep.2017.08.007

IBGE - Instituto Brasileiro de Geografia e Estatística. Área plantada, área colhida, quantidade produzida, rendimento médio e valor da produção das lavouras temporárias: banco de dados. 2018. Available from: <https://sidra.ibge.gov.br/Tabela/1612>. Accessed on: Jul. 10, 2019.

Khemkhao, M.; Nuntakumjorn, B.; Techkarnjanaruk, S.; Phalakornkule, C. UASB performance and microbial adaptation during a transition from mesophilic to thermophilic treatment of palm oil mill effluent. Journal of Environmental Management, v. 103, p. 74-82, 2012. https://doi.org/10.1016/j.jenvman.2012.03.004

Leme, R. M.; Seabra, J. E. Technical-economic assessment of different biogas upgrading routes from vinasse anaerobic digestion in the Brazilian bioethanol industry. Energy, v. 119, p. 754-766, 2017. https://doi.org/10.1016/j.energy.2016.11.029

Lora, E. E. S.; Venturini, O. J. Biocombustíveis. Rio de Janeiro: Interciência, 2012.

Ludovice, M. T. F. Estudo do efeito poluente da vinhaça infiltrada em canal condutor de terra sobre o lençol freático. Campinas: Universidade Estadual de Campinas, 1997. (Dissertação de mestrado).

Moraes, B. S.; Petersen, S. O.; Zaiat, M.; Sommer, S. G.; Triolo, J. M. Reduction in greenhouse gas emissions from vinasse through anaerobic digestion. Applied Energy, v. 189, p. 21-30, 2017. https://doi.org/10.1016/j.apenergy.2016.12.009

Moraes, B. S.; Zaiat, M.; Bonomi, A. Anaerobic digestion of vinasse from sugarcane ethanol production in Brazil: Challenges and perspectives. Renewable and Sustainable Energy Reviews, v. 44, p. 888-903, 2015. https://doi.org/10.1016/j.rser.2015.01.023

Nakashima, R.; Oliveira Junior, S. Comparative exergy assessment of vinasse disposal alternatives: Concentration, anaerobic digestion and fertirrigation. Renewable Energy, v. 147, p. 1969-1978, 2020. https://doi.org/10.1016/j.renene.2019.09.124 
Pecora, V.; González Velázquez, S. M. S.; Coelho, S. T. Aproveitamento do biogás proveniente dos resíduos sólidos urbanos para geração de energia elétrica: Estudo de caso em São Paulo. Anais do Congresso Internacional de Bioenergia, Curitiba, Universidade Federal do Paraná, 2009.

Ribas, M. Tratamento de vinhaça em reator anaeróbio operado em batelada sequencial contendo biomassa imobilizada sob condições termofílicas e mesofílicas. São Carlos: Universidade de São Paulo, 2007. (Dissertação de mestrado).

Salomon, K. R. Avaliação técnico-econômica e ambiental da utilização do biogás proveniente da biodigestão da vinhaça em tecnologias para geração de eletricidade. Itajubá: Universidade Federal de Itajubá, 2007. (Tese de doutorado).

SIAMIG - Sindicato da Indústria de Fabricação do álcool no Estado de Minas Gerais. Boletim Mensal da Produção 2018/2019. 2019. Available from: <http://www.siamig.com.br/uploads/369546354c9f44c7a6ef918a7e40f8e0.pdf>.

Accessed on: Jul. 10, 2019.

Wilkie, A. C.; Riedesel, K. J.; Owens, J. M. Stillage characterization and anaerobic treatment of ethanol stillage from conventional and cellulosic feedstocks. Biomass and Bioenergy, v. 19, no. 2, p. 63-102, 2000. https://doi.org/10.1016/S0961-9534(00)00017-9

License information: This is an open-access article distributed under the terms of the Creative Commons Attribution License, which permits unrestricted use, distribution, and reproduction in any medium, provided the original work is properly cited. 